\title{
Evolving UK policy on diversity in the armed services: multiculturalism and its discontents
}

\author{
Professor David Mason, Nottingham Trent University, UK \\ Professor Christopher Dandeker, King's College, London, UK
}

Addresses for correspondence:

\author{
Professor David Mason \\ Emeritus Professor of Sociology \\ The Graduate School \\ College of Business, Law and Social \\ Sciences \\ Nottingham Trent University \\ Burton Street \\ Nottingham \\ NG13 8QH \\ United Kingdom \\ E-mail: david.mason@ntu.ac.uk
}

\author{
Professor Christopher Dandeker \\ Professor of Military Sociology \\ Department of War Studies \\ Kings College, London \\ The Strand \\ London \\ WC2R 2LS \\ United Kingdom \\ E-mail: christophe.dandeker@kcl.ac.uk
}




\section{Evolving UK policy on diversity in the armed services: multiculturalism and its discontents}

Professor David Mason, Nottingham Trent University, UK

Professor Christopher Dandeker, King's College, London, UK

Abstract

Reflecting a generally multiculturalist rhetoric, UK policy in this area has hitherto focussed on enhancing the degree to which the armed services represent or reflect the ethnic makeup of the UK population. Ambitious targets have been set and some progress made in moving towards them. However, the dynamics of population change, together with the diverse preferences of ethno-religious minorities, have meant that the goal of representativeness has remained out of reach. At the same time, the armed services have continued to struggle with an ongoing recruitment problem while the volume of operational commitments has shown little sign of reducing.

The authors have previously argued that the heritage of empire has been a key background factor, from the perspective both of the armed services and of potential minority ethnic recruits. Since 11 September, 2001, a further series of complicating circumstances has entered the arena. The 'war on terror' has generated a clear sense of marginalisation among some of Britain's Muslim minorities, while the participation of British-born Muslims in the 2 July, 2005 attacks in London has raised new questions about the relationship between formal citizenship, identity, rights and duties. It has also led to the very principle of multiculturalism, long challenged by both the white right and black nationalists, being increasingly questioned across the political spectrum.

\section{Introduction}

This paper draws on and develops the ideas presented in the authors' previous published contributions to the discussion of the United Kingdom Government's evolving policy on the recruitment of minority ethnic groups to the armed services (Dandeker \& Mason, 2001; 2003; 2007). This policy, aimed at addressing the apparent under-representation of Britain's citizens of minority ethnic descent when compared with their presence in the population as a whole, has its origins in the 1998 Strategic Defence Review White Paper (SDR) (MINISTRY OF DEFENCE, 1998), which for the first time set targets for the recruitment of minority ethnic personnel.

In this paper, we revisit our analysis of the arguments that underpinned the SDR commitments and consider what progress has been made in meeting the targets 
set. In seeking to identify outstanding issues and emergent problems, we draw attention to continuing inconsistencies in wider Government policy towards nationality and citizenship which reflect the persistent societal uncertainties of an ex-colonial power.

\section{Arguments for equity: fairness, citizenship and effectiveness}

As we have noted elsewhere (Dandeker \& Mason, 2001), equal opportunities measures are characteristically justified in terms of two kinds of arguments: those that appeal to fairness and citizenship and those that appeal to self-interest. Both resonate with themes in SDR and have been implicated in the armed forces reexamination of a range of traditional practices and assumptions.

In addition, both EU and domestic law increasingly constrain the context in which the armed services must operate. In particular, the Race Relations Amendment Act (2000), together with subsequent statutory regulations, has placed a duty on all public bodies to take positive steps not only to eliminate discrimination but also to promote racial equality.

SDR, for the first time, set out targets for the recruitment of minority ethnic personnel, with a commitment to ensuring that 'the composition of our Armed Forces reflects that of the population as a whole.' (MINISTRY OF DEFENCE 1998: Supporting Essay 9, para. 41)

41. Ethnic Minorities. We are determined that the Armed Forces should better reflect the ethnic composition of the British population. Currently some $6 \%$ of the general population are from ethnic minority backgrounds, but they make up just $1 \%$ of the Services. This must not continue. We have set a goal of attracting $2 \%$ of new recruits this year from ethnic minority communities for each Service. We want that goal to increase by 
$1 \%$ each year so that, eventually, the composition of our Armed Forces reflects that of the population as a whole. ${ }^{1}$

These targets were underpinned by the two kinds of arguments referred to above: first, that proportional representation is a worthy goal in its own right since issues of fairness and citizenship are at stake; and second, that there is a 'business case', itself with several dimensions.

Probably the most pressing of the business case drivers has been the continuing and chronic problem of under-recruitment. ${ }^{2}$ Meeting the targets enshrined in SDR and subsequent policy pronouncements would, it has been argued, secure access to a wider recruitment pool as the armed services compete with civilian companies for scarce labour both in terms of quantity and quality. In this context, we can point to the fact that minority ethnic groups, although comprising 7.9 per cent of the population of the United Kingdom and 9.0 per cent of the population of England at the time of the 2001 Census, constitute a much larger proportion of the younger age groups most relevant to current and future military recruitment. Thus the Mixed group had the youngest age structure, with 50 per cent under the age of 16 . Thirty-eight per cent of both the Bangladeshi and Other Black groups were aged under 16, and 35 per cent of Pakistanis also fell into this age group. This was almost double the proportion of the White British group where one in five (20 per cent) were under the age of 16 (National Statistics, 2004). These data also need to be set against wider evidence of a generally ageing population.

Paradoxically, however, these data also cast doubts on the targets for representation established by Government. From an equity perspective, it is widely accepted among equal opportunity professionals that the relevant recruitment target for any occupation should be the proportion of minority ethnic persons in the relevant recruitment pool. As these data show, that proportion is 
significantly higher than the current target of $8 \%$ minority representation by 2013 (see note 1 ).

Other business case arguments include the claim that contemporary demands on the armed services, including enhanced peacekeeping and peace-enforcing roles, place a premium on more intelligent, flexible and diverse service personnel able to contribute to an ever wider range of challenges. With educated and qualified personnel increasingly at a premium, the higher levels of post-16 educational participation among members of some minority ethnic populations are said to provide the Services with a useful additional pool of skilled labour.

\section{Progress towards the target of representativeness?}

Despite the persuasiveness of these arguments, at least to military policy makers, progress in increasing the recruitment and retention of members of minority ethnic groups has been painfully slow. The targets set by the SDR, and subsequently modestly revised, have proved difficult to attain, even with the aid of what might be seen as some creative accounting.

Following disappointing results in the early years, more recent data do appear to show the policy first enunciated in the SDR beginning to pay dividends, with evidence of greater success in recruiting minority ethnic personnel in the most recent years for which data are available. On the face of it, the figures are beginning to approach the government's targets and to edge closer to the proportion of the population recorded by the 2001 Census as of minority ethnic origin, although we should be mindful of the earlier discussion of the age distributions of different communities.

Table 1 contains data relating to recruitment and shows a broadly upward trend, at least to the end of financial year 2005/06. As a result of this improvement, a 
Ministry of Defence press release (23 February, 2006) was able to claim:

The percentage of UK Regular Forces from ethnic minority backgrounds continues to rise; at 1 January 2006 ethnic minorities accounted for 5.5 percent compared to 5.2 percent at 1 January 2005. The largest increase was in the Army, where ethnic minorities comprised about 8 percent of regular forces by mid-2006 (Ministry of Defence, 2006).

Table 1

Minority Intake to Untrained Strength of UK Regular forces by Service (percentages, excluding unknown)

\begin{tabular}{|l|l|l|l|l|l|l|l|l|l|}
\hline & $\begin{array}{l}1998 \\
/ 09\end{array}$ & $\begin{array}{l}1999 \\
/ 00\end{array}$ & $\begin{array}{l}2000 \\
/ 01\end{array}$ & $\begin{array}{l}2001 \\
/ 02\end{array}$ & $\begin{array}{l}2002 \\
/ 03\end{array}$ & $\begin{array}{l}2003 \\
/ 04\end{array}$ & $\begin{array}{l}2004 \\
/ 05\end{array}$ & $\begin{array}{l}2005 \\
/ 06\end{array}$ & $\begin{array}{l}2006 \\
/ 07\end{array}$ \\
\hline $\begin{array}{l}\text { All } \\
\text { personnel }\end{array}$ & $\mathbf{1 . 8}$ & $\mathbf{1 . 7}$ & $\mathbf{2 . 9}$ & $*$ & $\mathbf{6 . 7}$ & $\mathbf{7 . 3}$ & $\mathbf{6 . 7}$ & $\mathbf{5 . 5}$ & $*$ \\
\hline Officers & $\mathbf{1 . 9}$ & $\mathbf{1 . 3}$ & $\mathbf{2 . 1}$ & $*$ & $\mathbf{2 . 9}$ & $\mathbf{2 . 3}$ & $\mathbf{2 . 6}$ & $\mathbf{2 . 4}$ & $*$ \\
\hline $\begin{array}{l}\text { Naval } \\
\text { Service }\end{array}$ & 1.2 & 1.3 & 2.1 & $*$ & 1.7 & 0.3 & 1.6 & 2.0 & $*$ \\
\hline Army & 1.5 & 0.6 & 1.5 & $*$ & 2.9 & 3.2 & 3.1 & 2.9 & $3.6^{\text {p }}$ \\
\hline $\begin{array}{l}\text { Royal Air } \\
\text { Force }\end{array}$ & 3.1 & 2.9 & 2.9 & $*$ & 4.6 & 2.1 & 2.8 & 1.7 & $*$ \\
\hline $\begin{array}{l}\text { Other } \\
\text { ranks }\end{array}$ & $\mathbf{1 . 8}$ & $\mathbf{1 . 8}$ & $\mathbf{2 . 9}$ & $*$ & $\mathbf{6 . 9}$ & $\mathbf{7 . 7}$ & $\mathbf{7 . 1}$ & $\mathbf{5 . 8}$ & $\mathbf{7 . 2 ^ { \mathbf { p } }}$ \\
\hline $\begin{array}{l}\text { Naval } \\
\text { Service }\end{array}$ & 1.6 & 1.4 & 1.9 & $*$ & 3.3 & 3.8 & 3.5 & 3.9 & 4.2 \\
\hline Army & 2.0 & 2.0 & 3.6 & $*$ & 9.2 & 10.2 & 8.9 & 6.7 & $8.2^{\text {p }}$ \\
\hline $\begin{array}{l}\text { Royal Air } \\
\text { Force }\end{array}$ & 1.2 & 1.2 & 1.7 & $*$ & 2.2 & 1.6 & 2.3 & 1.8 & 1.5 \\
\hline
\end{tabular}

Source: Defence Analytical Services and Advice (DASA) ${ }^{3}$

* Data unavailable

p Provisional

Despite this evidence of progress, however, it is necessary to enter some important caveats. The first is that despite an upward trend since the publication of the SDR, there remains a gap between the proportions of minority ethnic military personnel and the representation of the relevant groups in the population at large. This gap is widened further when differential age structures are taken into account. Moreover, latest figures suggest a possible fall-off in recruitment from a peak in 2003/04. ${ }^{4}$ 
Closer inspection of the data also suggests that there may have been a spurt in recruitment of minority ethnic personnel between 2002 and 2005 which may not necessarily be sustained. ${ }^{5}$

Second, there are important differences between service arms as well as between officer and other ranks recruitment. Greatest progress seems to have been made in the army, which is also home to the largest numbers of minority ethnic personnel, whilst naval service and RAF recruitment still lag behind target. Both the total numbers and the percentage of minority ethnic personnel entering the officer corps remain very low.

A third caveat concerns the conceptualization of 'minority ethnic'. As we have noted elsewhere (Dandeker \& Mason, 2003), this gross category takes no account of the different socio-demographic profiles, levels of social mobility, educational attainment and cultural traditions of the very diverse groups which make up Britain's minority ethnic population. As a result, it is entirely conceivable that the gross target of increasing minority ethnic representation to a level commensurate with the proportion of the population classified as 'ethnic minority' could be reached without representativeness being achieved for some of the communities involved. ${ }^{6}$ It is arguable that the progress that has been made in closing the gap in relation to recruitment targets exemplifies this problem, since the recruitment of indigenous minorities is significantly skewed towards those classified as 'Black' - i.e., of Caribbean (and ultimately African) descent, including many with 'mixed' heritage. South Asian descended personnel remain under-represented in the armed services to the point of near-invisibility.

A further, serious conceptual and practical complication is that many of those classified as 'ethnic minority' are, in fact, Commonwealth citizens. Thus, although they are excluded from the figures presented in Table 1, we should note that Fijians, 
Vincencians and St Lucians, recruited en bloc to the Army, represented more than one third of those recorded as ethnic minority recruited in 2002/03. (This figure was itself down from half in the two previous years for which figures are available.) To this must be added Commonwealth citizens recruited individually in the UK (and who are included in the data in Table 1). This means that, despite evidence of more success in recruiting ethnic minorities, a substantial proportion of 'minority ethnic' personnel (approximately 60 per cent in the case of the army) are, in fact, Commonwealth and other non-UK citizens rather than British citizens. Indeed, there is some evidence that the apparently improved recruitment of minority ethnic personnel coincided with a conscious decision by the Ministry of Defence to target commonwealth citizens to meet recruitment shortfalls.

This distinction is important in the context of the history of differential and conditional incorporation during the imperial phase of Britain's past, not least because Commonwealth citizens are not British Citizens and are thus not entitled to the full suite of citizenship rights available to British Citizens. This in turn raises three questions: Does increasing diversity by these means really fulfil the spirit of the SDR commitments? What implications does non-citizen status have for incorporation on equal terms within the military team? What, if any, are the implications for operational effectiveness?

The non-British component of the Army, in particular, is very significant, representing nearly two thirds of serving minority ethnic personnel at 1 January, 2007, with 56 nationalities represented. By late 2005, concerns about the dependence of the army on foreign nationals were sufficiently strong for the matter to reach the attention of the press, for active recruitment of Commonwealth and foreign personnel to cease and for suggestions to begin to emerge from military and other sources that a limit be placed on the proportion of non-British army personnel. The Times reported the matter under the headline, 'How British Army is fast 
becoming foreign legion':

THE Army has stopped actively recruiting Commonwealth and foreign soldiers because the numbers joining up have risen by nearly 3,000 per cent in seven years. ...

However, in recent years, many regiments would not have survived without the influx of recruits from the Commonwealth, particularly from Fiji, Jamaica, South Africa and Ghana, because of drastic manpower shortages. Soldiers from overseas now account for 6 per cent of the Army's strength, rising to 9 per cent if the 3,000 Gurkhas recruited from Nepal are taken into account.

Last year the 1st Battalion The Princess of Wales's Royal Regiment had 116 overseas and Commonwealth citizens serving in its ranks, representing about 20 per cent of the total strength. The Black Watch had 31 Commonwealth soldiers, most of them Fijian.

The overseas recruits are regarded as high-quality soldiers who have played an increasingly important role in operations such as Iraq and Afghanistan. Many have won gallantry medals: Private Johnson Beharry, 25, who was awarded the Victoria Cross for saving the lives of his comrades in Iraq in 2003, was born in Grenada and was one of the 116 Commonwealth soldiers who joined the 1st Battalion The Princess of Wales's Royal Regiment. The problem for army chiefs is that the number of applicants from the Commonwealth has risen dramatically at the same time as recruits from within the United Kingdom have dropped significantly. General Sir Mike Jackson, Chief of the General Staff, revealed yesterday that in the last financial year recruitment had fallen 7 per cent short of the target.

Yet the Commonwealth figures show that numbers have risen from 205 in 1998 to about 6,000 this year. There are currently 5,500 Commonwealth and overseas soldiers serving in the UK Field Army and another 700 recruits are under training.

Other infantry regiments with a high proportion of overseas or Commonwealth soldiers include: The Royal Scots with 89 (the latest figures relate to November last year); the 2nd Battalion The Princess of Wales's Royal Regiment, 91; the 1st Battalion The Royal Green Jackets, 88; the 2nd 
Battalion The Royal Green Jackets, 107; and the Royal Gloucestershire, Berkshire and Wiltshire Regiment, 85. ...

With gaps appearing in many of the British infantry regiments, the Army began an intensive drive to recruit from the Commonwealth, and teams were sent far and wide, from the Caribbean to southern Africa, to offer careers in the British Army. The take-up was beyond all expectation.

The influx of Fijians was particularly welcomed, not just because of their military prowess but also because of their reputation as excellent rugby players. The Army's rugby team has benefited accordingly...

Figures released four years ago showed that the top Commonwealth recruiting countries were Fiji, followed by South Africa, Canada, Australia, New Zealand, Zimbabwe, Jamaica and India (Evans, 2005).

In the context of predictions that 'almost one in five soldiers in the British army could come from Commonwealth countries by $2020^{\prime}$, a vigorous debate ensued in both press and military circles through 2007 and $2008 .^{7}$ It culminated in a Government announcement, in February 2009, that an upper limit of $15 \%$ was to be placed on the foreign and Commonwealth complements of the three elements of the Army with the highest concentration of such personnel (the Royal Logistic Corps, the Royal Army Dental Corps and the Queen Alexandra's Royal Army Nursing Corps) (Hansard, 2009).

Leaving aside the fact that this decision may yet be subject to legal challenge, the change of policy represented by the introduction of a cap on Commonwealth recruitment, and the concerns that it reflects, - has wider implications for British conceptions of nationality and citizenship which remain contested and unresolved. We return to this issue below.

\section{Differential incorporation or voluntary exclusion}


The recruitment targets originating in SDR and subsequently periodically revised were justified on the basis of improved representativeness, or a socio-demographic match between the military and society. However, both the large numbers of nonBritish minority personnel and the under-representation of South Asians raise questions about the extent to which, even with improved performance against the SDR targets, the armed forces are really more representative of British society. It suggests that new-found diversity is, in practice, limited in scope.

There are various possible explanations for the under-representation of South Asian personnel. They include deliberate exclusion (discrimination) and ineffective recruitment efforts. It may, however, be the result of an explicit unwillingness to enlist. The armed services have long tended to see the barriers to improving the recruitment of minority ethnic personnel as lying within minority ethnic communities; in ignorance about the opportunities afforded by the services or in concern about a past racism that is now said to be being addressed. There is some evidence that there is an element of truth in all these explanations. But there are also some indications of a more general sense that the armed forces do not really 'belong' to minority ethnic citizens and that this also explains the apparent reluctance of some groups to enlist (Hussain \& Ishaq, 2002).

As we have argued before, however, there are dangers in reading voluntary exclusion simply in cultural terms. This practice represents a particular variant of a tendency, in both the academic and policy literature relating to ethnic difference in Britain, to assume that wherever putative ethnic differences have been identified, ethnicity must be the principal explanatory variable (see Mason, 2003 a \& b).

Given the differences that are known to exist between groups in their propensity to select particular occupations or to aspire to particular careers, it is likely that cultural preferences play only a part in decisions about whether or not to join the armed 
services. ${ }^{8}$ Focussing on them can easily provide an excuse for not addressing the deficiencies of existing organisational structures and practices.

Closer analysis of patterns of social and occupational mobility among Britain's minority ethnic citizens suggests that we should not underestimate the role of rational decision-making in occupational placement.

The last few decades have seen marked upward mobility among members of some minority ethnic groups in Britain (Iganski \& Payne, 1996 \& 1999). As a result, even some of the previously most disadvantaged groups, Pakistanis and Bangladeshis, have significantly closed the gap with whites in terms of economic activity, unemployment and job levels (Iganski \& Payne, 2000; Mason, 2003 a \& b).

As a result, we need to place any discussion of the attractiveness to potential minority ethnic recruits of a career in the armed services in the context of the range of other opportunities open to them. Such opportunities include further and higher education, with the evidence indicating that members of minority ethnic groups are more likely to remain in full-time education after the age of 16 than are their white counterparts (Modood, et al., 1997; Modood \& Ackland, 1998.); Modood \& Shiner, 1994). In this context, we should note that survey evidence about the attitudes to military service of minorities of Pakistani Muslim descent in Britain revealed a tendency to prioritize further and higher education over enlistment in what was often seen as a low status occupation (Hussain \& Ishaq, 2002). There is a strong possibility, moreover, that these sentiments have now been compounded by questions surrounding the legitimacy of the armed forces' missions over the past few years in Afghanistan and Iran.

Any analysis of the potential attractiveness of a military career must be placed in 
this broader context. Measured against other opportunities, it may be that a military career is simply not sufficiently attractive. It is, perhaps, no coincidence that, whilst members of Britain's South Asian minority ethnic groups appear reluctant to enter the nursing profession, there is no shortage of applicants from these same groups for careers as doctors (Iganski \& Mason, 2002).

This line of argument is also consistent with the recruitment patterns discussed above. It is a commonplace that labour market disadvantage has often been associated with increased willingness to enlist, as the old adage that unemployment is the best recruitment sergeant attests. (Or as a contributor at the 2006 IUS Canada Conference put it, 'We recruit the best of the desperate.') We noted above that British citizens classified as Black are significantly over-represented among indigenous minorities joining the armed forces. They are also among the groups that continue to experience significant labour market disadvantage.

\section{The challenge of increased numbers and enhanced diversity}

Notwithstanding the various caveats rehearsed above, it is clear that, for whatever reasons, there has been a growth in the numbers of minority personnel in the UK armed forces and, particularly, the army. This in turn poses its own challenges.

Elsewhere we have argued that these challenges include the emergence of issues relating to retention, including advancement (the potential emergence of an 'armoured glass ceiling'), exclusionary occupational cultures and persistent reports of bullying and harassment (Dandeker \& Mason, 2007). We shall not rehearse these issues again here. Instead, we want to suggest that a diversity that embraces not merely UK citizens of minority descent but also Commonwealth and foreign citizens highlights and exacerbates some existing uncertainties about how that diversity is to be understood and accommodated. Those uncertainties relate not only to the impact on the armed services themselves but to the way the relevant issues are framed in wider political and social discourse. 
A key danger is that of conditional inclusion. Minorities have not always been excluded from the British armed services. Indeed, the policing and defence of Empire led to the recruitment of large numbers of imperial subjects to the armed forces. Many served Britain in both world wars. However, the Empire's inclusion of such personnel was always highly conditional. They were frequently recruited to separate units officered by British personnel; an arrangement that continues to apply in the special case of the Gurkhas. Elsewhere, imperial subjects were often employed in low status roles in otherwise white units. The example of black cooks, stewards and stokers in otherwise white crewed Royal Naval vessels was a case in point (Smith, 2004: 60).

Is it possible that the growth in the numbers of Commonwealth citizens recruited to the army could lead to a comparable conditional inclusion? There is currently no policy of recruiting Commonwealth and foreign soldiers to separate units and, although it is occasionally mooted, there is no evidence of such an initiative having acquired serious legitimacy or momentum. Nevertheless, there is some evidence that the growing numbers of such personnel have, hitherto at least, been concentrated in particular regiments (see the Times article quoted above). More significantly, there are at least some suggestions that these personnel feel particularly marginalised within the units within which they serve and experience a double disadvantage on the basis both of ethnicity and citizenship. Reporting on the setting up of the British Commonwealth Soldiers' Union, the BBC quoted its founder, a Belize born soldier:

Commonwealth soldiers are third-class soldiers. First you have the Britishborn white soldier, then the British-born black soldier, then the black Commonwealth soldier. In some units, white soldiers will be given priority for 
courses over black soldiers, and the black soldier - no matter how long he's been in - will be put behind the white soldier (BBC News, 2007).

Were such experiences to be widespread, it is not difficult to see how they could seriously affect both the army's reputation among minorities (with knock-on consequences for future recruitment) and its operational effectiveness. If the armed forces are to build on the admittedly limited successes of recent recruitment rounds, they have to address this perception of conditional inclusion. This, as we have argued elsewhere, (Dandeker \& Mason, 2003; 2007) involves rising to the fundamental challenge of embracing and delivering a diversity relevant to the aims of the armed forces and the state by placing it within a shared framework of values and expectations. Difference must be accommodated to the need for discipline and cohesion.

This task, however, is difficult to accomplish for a military serving a society that itself has yet effectively to rise to the challenges posed by its recent history and contemporary demographic makeup. We have argued elsewhere that the heritage of Empire continues to weigh heavily on the British national psyche (Dandeker \& Mason, 2007). One of its consequences is a schizophrenic attitude to the Commonwealth, a body both celebrated as the embodiment of the positive legacy of empire and experienced as a reminder of the extent to which the power once wielded by the 'mother country' has been challenged and attenuated. It is not implausible to see this ambivalence being reflected both in the decision to systematically pursue Commonwealth personnel as a solution to the military recruitment shortfall and as the spur to concerns that the 'Britishness' of the army might be under threat.

This schizophrenia is arguably not new. It is also manifested in the history of Britain and its military over the last two centuries or so. As we have argued before 
(Dandeker \& Mason, 2001), the recent forebears of many of Britain's citizens who are not white encountered the armed forces either as enemies or colonial subjects. If it has been difficult to view their descendants as co-nationals because they lack the common origins and the ethnic homogeneity which the British national myth requires, how much more difficult might it be unequivocally to embrace as comrades-in-arms Commonwealth personnel who cannot even lay claim to formal citizenship?

It is difficult to overstate the impact of these distinctive features of British national self-conceptions. They diverge significantly from those of the United States, whose origin myths emphasise diversity and whose official national values centre on a contractually devised constitution. There have, however, been other developments in recent years that have complicated British attempts to come to terms with a postcolonial identity in which large numbers of former colonial subjects are now co-equal citizens.

\section{Multiculturalism and its discontents}

The policy first enunciated in the SDF was framed in terms of a conventional multiculturalism. This drew strongly on a famous definition of integration offered by the then Home Secretary, Roy Jenkins, in 1966:

I define integration, therefore, not as a flattening process of assimilation but as equal opportunity accompanied by cultural diversity, in an atmosphere of mutual tolerance. (Quoted in Brighton, 2007)

The concept of multiculturalism has always been a contested one and there are few, if any, agreed definitions (see the discussion in Parekh, 2006). In its most 'official' British manifestation, however, it has tended to imply a commitment to political integration accompanied by incorporation on equal terms within the public sphere 
on the basis of a set of common civic values. These values themselves are intended to be sufficiently flexible to accommodate limited cultural variation - such as dress and dietary requirements and the mutual public celebration of religious and other festivals - while consigning a much greater degree of culturally based difference to the realm of the private (Rex, 1985 , especially page 6 ).

The commitment to multiculturalism, even in this limited sense, was never fully accepted across the political spectrum, particularly on the radical right and left and in sections of some minority communities. However, it is fair to say that until relatively recently it had become an elite orthodoxy, at least at a rhetorical level. In recent years, however, much has changed.

The events of 11 September, 2001, were a key turning point, reinforcing already emerging concerns in some parts of the British polity that the demands of Muslim communities, in particular, could not be accommodated within the existing multicultural settlement. ${ }^{9}$ These concerns were reinforced by the events of July 2005 when terrorist attacks were perpetrated in London by young British Muslims. The result was a clear re-orientation of the rhetoric of integration with the emergence of much more explicit that hitherto assimilationist overtones (Brighton, 2007: 7-8).

Even before the full implications of these terrorist outrages had become apparent, urban disorders in a number of cities in the north of England in the summer and autumn of 2001 had begun to ring alarm bells in government and other circles. Once again, the disturbances appeared to be evidence of a breakdown of the multicultural accommodation and, again, Muslim young men seemed to be at the centre of events. ${ }^{10}$ Analyses of the events produced evidence, in particular, of significant residential segregation, particularly of Muslim communities, with knockon effects for educational provision and patterns of day to day interaction. In the 
face of this information, many commentators, together with Government ministers, concluded that processes of self-segregation were at work which not only breached the principles of the multicultural settlement but threatened what was to become known as community cohesion. ${ }^{11}$ The search commenced for improved ways to secure the integration of Britain's diverse ethic communities, with the emphasis once again particularly focussed on Muslims. The diagnoses produced focussed above all on two alleged causal factors: the radicalising activities of some Muslim clerics and the intrusion of cultural practices, properly the province of the private sphere, into the public realm. Recent debates, initiated by ex-Government minister Jack Straw, concerning the wearing of the Hijab or veil exemplify this point (BBC News, 2006).

All of these debates implicitly, if not explicitly, involve a questioning of the nature of the commitment of Muslim citizens to a cohesive community and, at least potentially, call into question their loyalty to the nation state - with obvious implications for their role in the armed forces.

Many of these discussions and diagnoses have fallen victim to a tendency to essentialise Islamic communities, ignoring national, communal and doctrinal differences (for example, between Turks, Bangladeshis, Gujerati Muslims and Pakistanis in various parts of the UK). In practice, there is no strong evidence either that Muslim personnel are especially victim to divided loyalties or that in other circumstances other groups would not experience tensions of this kind. Indeed, evidence from the 2001 Census suggests that the vast majority of all those affirming membership of a minority ethnic group also unequivocally described their national identity as British, English, Scottish or Welsh.

This included almost nine in ten people from a Mixed (88 per cent) or Black Caribbean (86 per cent) group, around eight in ten people from a Pakistani 
(83 per cent), Bangladeshi (82 per cent) or Other Black (83 per cent) group, and three quarters (75 per cent) of the Indian group (National Statistics, 2006).

Yet the persistence of speculation about this issue, taken together with a popular tendency, in Britain at least, to demonise all Muslims as potentially fundamentalists or terrorists has clear consequences for attempts to re-imagine Britain in the $21^{\text {st }}$ Century (Dandeker \& Mason, 2003). In a military context, of course, such persistent speculation has clear potential implications for the experience of Muslim recruits and hence for the ability to meet recruitment targets. To the extent that these wider political and social debates are replicated among service personnel, as surely they must be, they also have the potential to threaten unit cohesion, the goal of which is, of course, the tested solution to problems of loyalty, commitment and, crucially, military effectiveness.

The rethinking of the multicultural settlement does not, however, depend solely on the rise of concerns about segregated and radicalised Muslim communities. It also reflects a wider set of debates about immigration. These debates have been reinvigorated both by the increases in the numbers of asylum seekers and political refugees arriving in Britain in the last decade and by increases in immigration from the new EU states of eastern Europe. The message of those increasingly questioning old-style multiculturalism is that it has emphasised and promoted difference and separation (sometimes represented as a kind of 'tribalism') at the expense of mutual trust, tolerance and a sense of a wider, shared community of belonging. ${ }^{12}$

One response has been a renewed emphasis on the importance of integration conceived more narrowly than in the multicultural version. This has included the development of citizenship education classes and new tests of language and civic competence for those seeking British Citizenship by naturalization. Once again, the 
emphasis is on a conception of 'integration' that goes beyond the tolerance of cultural difference towards a distinctly more assimilationist model. This is not one that primarily emphasises acculturation but rather one with a clear focus on commitment to shared and renewed civic values.

It is not difficult to see the changes of policy towards the recruitment of Commonwealth troops as part of this wider process of rethinking the national and citizenship project.

This rethinking requires the squaring of more than one circle. How does Britain come to terms with its post-imperial status while maintaining a commitment to an international diplomatic and expeditionary military role? How can its hitherto strongly ethnicist conception of nationality be reconciled with a world in which large scale migration and settlement is both a fact of life and the sine qua non of economic success? And how can existing citizenship rules, framed largely in terms of an earlier debate about immigration and a primordialist view of nationality, be accommodated to what looks increasingly like an emerging contractual, civic conception of citizenship - if one that is yet to be fully and clearly articulated?

The growing challenge to multiculturalism - itself contested and frequently contradictory - has yet to result in a clear alternative vision. At best we can discern tentative movements towards a more integrationist vision, marked by a flirtation with a civic, contractual model of citizenship yet unwilling to abandon entirely a sense of nationhood rooted in a primordialist view of history. Whether a resolution is either imminent or possible must remain a matter of speculation, as must the question of whether it will be driven by principle or by a frequently underestimated British capacity for pragmatism.

\section{Conclusion}


In an earlier paper, we concluded as follows:

The Armed Services are the servants and representatives of a wider society, doing its bidding, reflecting its traditions and defending its values. But this raises the question of what it is they are to be representative (or reflective) of. The challenge of securing the inclusion of minority ethnic citizens - of creating the conditions in which diversity can be valued in all aspects of social life - is a national one, not just a task for the armed forces. In Britain, this entails nothing less than completing the task of re-imagining the nation in the $21^{\text {st }}$ Century (Dandeker \& Mason, 2007: 151).

We see no reason to revise this view, although the circumstances in which that reimagining is to take place have dramatically changed. Whilst it is right and proper that we demand of the Armed Services that they continue to seek more fully to represent the nation they serve, it will only be when that nation has a clearer view of its desired shape and direction that the task can be fully accomplished.

\section{Notes}

${ }^{1}$ Note that the population figure in this statement has been superseded by the results of the 2001 Census, which shows that some $9 \%$ of the population of England affirmed minority ethnic group membership. The target for minority ethnic recruitment has also been raised from an initial aim of $6 \%$ by 2006 to $8 \%$ by 2013 (Ministry of Defence, nd).

2 There is evidence that recruitment and retention levels have improved in the last twelve months. This improvement is attributed by Government sources to initiatives to improve pay and conditions (Ministry of Defence, 2009). Others have suggested that recruits have been attracted by the challenges of current operations and the honours that have been conferred on those who have served with distinction. It is also possible that the recession has had some effect. We are not currently in a position to evaluate the evidence for these different possible explanations. In any event, it would be unwise, at this early stage, to base a revamp of policy on what may turn out to be a short-term improvement.

${ }^{3}$ Data from 2002/03 onwards are taken from Ministry of Defence, 2007. Earlier data were compiled from DASA sources for earlier publications by the authors. A recoding exercise, to reflect revised Census categories, means that no ethnicity data are available for 2001/02. Note also that army data for 2006/07 are described by DASA as provisional owing to the ongoing validation of data from a new personnel administration system.

${ }^{4}$ It would be unwise to draw conclusions at this stage from incomplete and provisional 2006/07 data. 
${ }^{5}$ It is also possible, of course, that the wars in Iraq and Afghanistan may have had a depressive effect on the recruitment of minority personnel.

${ }^{6}$ Research has demonstrated patterns of this kind in the nursing workforce, for example (Iganski \& Mason, 2002).

${ }^{7}$ See, for example, Norton-Taylor (2008); The Times of India (2008).

${ }^{8}$ We know, for example, that most 'whites' do not enlist and that those who do tend to be drawn from highly traditional and geographically discrete recruitment pools. See Dandeker \& Strachan, 1993 and Strachan, 2002.

9 The Salman Rushdie affair was an earlier case in point. See the discussion in Brighton, 2007.

10 See the discussions in Mason, 2003c.

11 In fact, there was little convincing evidence that residential segregation was self-imposed and many indications that it resulted from the operation of the local housing markets. See Harrison, 2003 and Finney \& Simpson, 2009.

12 For a flavour of the debates that have emerged in recent years, see Phillip, 2004; Jasper, 2005; BBC News, 2005; BBC News, 2008. For an assessment of some of the more alarmist contributions, see Finney \& Simpson, 2009. 


\section{References}

Brighton, S. (2007) British Muslims, multiculturalism and UK foreign policy: 'integration' and 'cohesion' in and beyond the state, International Affairs 83 (1), pp.1-17.

BBC News (2005) Davis attacks UK multiculturalism, Wednesday, 3 August. Available at http://news.bbc.co.uk/1/hi/uk politics/4740633.stm (accessed 07 January, 2008).

BBC News (2006) Straw's veil comments spark anger, Thursday, 5 October. Available at http://news.bbc.co.uk/1/hi/uk politics/5410472.stm (accessed 07 January 2008).

BBC News (2007) Commonwealth soldiers form union, Wednesday, 7 March. Available at http://news.bbc.co.uk/1/low/uk/6425529.stm (accessed 07 January, 2008).

BBC News (2008) Tory warning on multiculturalism, Sunday, 28 September. Available at http://news.bbc.co.uk/1/hi/uk politics/7639047.stm (accessed 29 September, 2008).

Dandeker, C. \& Strachan, A. (1993) Soldier Recruitment to the British Army: A Spatial and Social Methodology for Analysis and Monitoring, Armed Forces \& Society, 19(2), pp. 279-290.

Dandeker, C. \& Mason, D. (2001) The British armed services and the participation of minority ethnic communities: from equal opportunities to diversity? Sociological Review. 49(2), pp. 219-233.

Dandeker, C. \& Mason, D. (2003) Diversifying the uniform?: the participation of minority ethnic groups in the British armed services, Armed Forces and Society, 29(4), pp. 481507.

Dandeker, C. \& Mason, D. (2007) Ethnic diversity in the British armed forces, in: Soeters, J. \& Meulen, J. vd. (Eds.), Cultural diversity in the armed forces (Abingdon; New York: Routledge).

Evans, M. (2005) 'How British Army is fast becoming foreign legion', The Times, November 14. Available at http://www.timesonline.co.uk/tol/news/uk/article589974.ece (accessed 25 September, 2009).

Finney, N. \& Simpson, L. (2009) 'Sleepwalking to segregation?' Challenging myths about race and migration (Bristol, Policy Press) 
Norton-Taylor, R. (2008) MoD may halt surge in Commonwealth recruits to army, The Guardian, Saturday 5 April. Available at

http://www.guardian.co.uk/uk/2008/apr/05/military.defence (accessed 28 September, 2008).

Hansard (2009) Written Ministerial Statement on Army Nationality Policy. Available at http://www.publications.parliament.uk/pa/cm200809/cmhansrd/cm090202/wmstext/90 202m0001.htm Accessed February 2009

Harrison, M. (2003) Housing Black and minority ethnic communities: diversity and constraint, in: David Mason (ed.) Explaining Ethnic Differences: Changing Patterns of Disadvantage in Britain (Bristol: Policy Press).

Hussain, A. \& Ishaq, M. (2002) 'British Pakistani Muslims' Perceptions of the Armed Forces', Armed Forces \& Society, 28(4), pp. 601-618.

Iganski, P. \& Mason, D. (2002) Ethnicity, equality of opportunity and the British National Health Service (Aldershot: Ashgate Publications).

Iganski, P. \& Payne, G. (1996) Declining Racial Disadvantage in the British Labour Market, Ethnic and Racial Studies 19(1), pp. 113-134.

Iganski, P. \& Payne, G. (1999) Socio-Economic Re-Structuring and Employment: The Case of Minority Ethnic Groups, British Journal of Sociology, 50(20), pp. 195-216.

Iganski, P. \& Payne, G. (2000) Social Exclusion and Social Inclusion: Britain's Minority Ethnic Groups. Paper presented to the Cambridge Stratification Seminar, Claire College, Cambridge, 19-21 September.

Jasper, L (2005) Trevor Phillips is in danger of giving succour to racists, The Guardian, Wednesday 12 October. Available at http://www.guardian.co.uk/world/2005/oct/12/race.uk (accessed 07 January, 2008).

Mason, D. (2003a) Changing Ethnic Disadvantage: An overview, in David Mason (ed.) Explaining Ethnic Differences: Changing Patterns of Disadvantage in Britain (Bristol: Policy Press). 
Mason, D. (2003b) Changing Patterns of Ethnic Disadvantage in Employment, in David Mason (ed.) Explaining Ethnic Differences: Changing Patterns of Disadvantage in Britain, (Bristol: Policy Press).

Mason, D. (Ed.) (2003c) Explaining Ethnic Differences: Changing Patterns of Disadvantage in Britain, (Bristol: Policy Press).

Ministry of Defence (1998) The Strategic Defence Review, (London, Cm 3999, July).

Ministry of Defence (2006)

http://www.mod.uk/DefenceInternet/DefenceNews/PeopleInDefence/UkArmedForcesAt9 83PercentManning.htm Accessed 04 April, 2006

Ministry of Defence (2007) UK Defence Statistics 2007, Chapter 2 - Personnel. Available at http://www.dasa.mod.uk/modintranet/UKDS2007/c2/table217.html (accessed September 15, 2009).

Ministry of Defence (2009) Latest Armed Forces manning figures released, 27 February. Available at

http://www.mod.uk/DefenceInternet/DefenceNews/DefencePolicyAndBusiness/ArmedFor cesManningIncreases.htm (accessed September 16, 2009)

Ministry of Defence (nd) Equality and Diversity in the Armed Forces. Available at http://www.mod.uk/DefenceInternet/AboutDefence/WhatWeDo/Personnel/EqualityAndDi versity/EqualityAndDiversityInTheArmedForces.htm Accessed 15 September 2009

Modood, T. \& Ackland, T. (1998) Race and Higher Education (London: Policy Studies Institute).

Modood, T. et al. (1997) Ethnic Minorities in Britain (London: Policy Studies Institute);

Modood, T. and Shiner, M. (1994) Ethnic Minorities and Higher Education: Why Are There Differential Rates of Admission? (London: Policy Studies Institute).

National Statistics (2004a) Ethnicity \& Identity: Population Size. Available at http://www.statistics.gov.uk/cci/nugget.asp?id=456 (accessed 04 April, 2006).

National Statistics (2004b) Ethnicity \& Identity:Geographic Distribution. Available at 
http://www.statistics.gov.uk/cci/nugget.asp?id=457 (accessed 04 April, 2006).

National Statistics (2006) Ethnicity \& Identity: Identity. Available at

http://www.statistics.gov.uk/cci/nugget.asp?id=459 (accessed 04 April, 2006)

Phillips, T (2004) Multiculturalism's legacy is 'have a nice day' racism, The Guardian, Friday 28 May. Available at

http://www.guardian.co.uk/society/2004/may/28/equality.raceintheuk (accessed 07 January, 2008).

Rex, J. (1985) The Concept of a multi-cultural society, Occasional Papers in Ethnic Relations No. 3 (Warwick: Centre for Research in Ethnic Relations).

Smith, R. (2004) Jamaican Volunteers in the First World War: Race, Masculinity and the Development of National Consciousness (Manchester: Manchester University Press).

Strachan, H. (2002) Reassessing Recruitment Strategies for the Armed Services, in: A. Alexandrou, R. Bartle \& R. Holmes (Eds.) New People Strategies for the British Armed Forces (London and Portland OR: Cass).

The Times of India (2008)

http://timesofindia.indiatimes.com/World/UK may cap army recruitment from Comm onwealth countries/articleshow/292843 (accessed 28 September, 2008). 